\title{
Late Cretaceous mega-, meso-, and microfloras from Lower Silesia
}

\author{
Adam T. Halamski, Jiří Kvaček, Marcela Svobodová, Ewa Durska, and Zuzana Heřmanová
}

Acta Palaeontologica Polonica 65 (4), 2020: 811-878 doi:https://doi.org/10.4202/app.00744.2020

Late Cretaceous plants from the North Sudetic Basin (Lower Silesia, south-western Poland) are reviewed on the basis of megaflora from 17 localities (270 identifiable specimens), mesoflora from two localities, and microflora from four localities. Major sites are Rakowice Małe and Bolesławiec. Eight megafloral assemblages are distinguished (Assemblage 1, Turonian; Assemblages 2, 3, lower-middle Coniacian; Assemblages 4, 5, upper Coniacian?-lower Santonian?; Assemblages 6-8, lower-middle Santonian); the bulk of the palaeoflora is from Assemblages 4-6 and 8. Megaflora consists of 29 taxa (6 ferns, 4 conifers, and 19 angiosperms). Geinitzia reichenbachii is the most common species. Dryophyllum westerhausianum (Richter, 1904) Halamski and Kvaček comb. nov. is a trifoliolate leaf re-interpreted as a representative of Fagales. Three species of Dewalquea are distinguished: Dewalquea haldemiana, Dewalquea insignis , and Dewalquea aff. gelindenensis. Platanites willigeri Halamski and Kvaček sp. nov. is characterised by trifoliolate leaves, the median leaflet of which is ovate, unlobed, with a serrate margin, and cuneate base. Palaeocommunities inferred from the megafossil record include: a back swamp forest dominated by Geinitzia, with abundant ferns; a Dryophyllum-dominated riparian forest; a forest with Dewalquea and Platanites willigeri possibly located in the marginal part of the alluvial plain; dunes with D. haldemiana and Konijnenburgia; a fern savanna with patches of Pinus woodlands. Palynoassemblage A from the Nowogrodziec Member, studied mostly at Rakowice Małe and Żeliszów, consists of 126 taxa, including 105 terrestrial palynomorphs (54 bryophyte, lycophyte, and pteridophyte spores, 16 gymnosperms, 35 angiosperms). The mega- and mesofossil records are dominated by angiosperms; the palynoassemblages are dominated by ferns. Palaeocommunities represented solely by the microfossil record are halophytic (with Frenelopsis and unconfirmed presence of Nypa) and pioneer vegetation. Palaeocommunities are intermediate in general character between those pre-dating the Cretaceous Terrestrial Revolution and modern, angiosperm- dominated vegetation. In comparison to older plant assemblages from contiguous areas laurophylls are much rarer; this might correspond to a real phenomenon of exclusion of lauroids from Santonian riparian forests. The studied assemblage is more similar to younger palaeofloras than to older ones; this might be interpreted as stabilisation of communities after a period of pronounced change related to the rise to dominance of the angiosperms. In contrast to widespread endemism among vertebrates of the European Archipelago, the plant cover consists mostly of species that are widely distributed.

Key words: Angiospermae, Leptosporangiatae, palaeobotany, palynology, taxonomy, Coniacian, 
Santonian, Poland.

Adam T. Halamski [ath@twarda.pan.pl], Institute of Paleobiology, Polish Academy of Sciences, ul. Twarda 51/55, 00-818 Warszawa, Poland. Jiří Kvaček [jiri.kvacek@nm.cz ] and Zuzana Heřmanová [zuzka.hermanova@gmail.com], National Museum, Václavské náměstí 68, 11579 Praha 1, Czech Republic. Marcela Svobodová [msvobodova@gli.cas.cz ], Institute of Geology of the Czech Academy of Sciences, Department of

Paleobiology and Paleoecology, Rozvojová 269, 16500 Praha 6, Czech Republic.

Ewa Durska [edurska@uw.edu.pl], Faculty of Geology, University of Warsaw, ul. Żwirki i Wigury 93, 02-089 Warszawa, Poland.

This is an open-access article distributed under the terms of the Creative Commons Attribution License (for details please see creativecommons.org), which permits unrestricted use, distribution, and reproduction in any medium, provided the original author and source are credited. 